\title{
Characterization of Temperature Regime under Capsicum Cropped Naturally Ventilated Greenhouse
}

\author{
Nilesh Biwalkar ${ }^{1}$, Rakesh Kumar ${ }^{2 *}$ and Rakesh Sharda ${ }^{1}$ \\ ${ }^{1}$ Department of Soil and Water Engineering, Punjab Agricultural University, \\ Ludhiana, India - 141004 \\ ${ }^{2}$ Agricultural Engineering, PAU, Krishi Vigyan Kendra, Faridkot-151203 (Punjab), India \\ *Corresponding author
}

A B S T R A C T

\begin{tabular}{|c|}
\hline Keywords \\
\hline $\begin{array}{l}\text { Temperature } \\
\text { regime, Capsicum, } \\
\text { Greenhouse, } \\
\text { Horizontal and } \\
\text { vertical temperature }\end{array}$ \\
\hline Article Info \\
\hline $\begin{array}{l}\text { Accepted: } \\
\text { 10 March } 2020 \\
\text { Available Online: } \\
10 \text { April } 2020\end{array}$ \\
\hline
\end{tabular}

A $560 \mathrm{~m}^{2}$ naturally ventilated greenhouse (Fig. 1) was constructed at the research farm of Department of Soil and Water Engineering, Punjab Agricultural University, Ludhiana. A similar greenhouse was also constructed at Krishi Vigyan Kendra, Faridkot. Capsicum was cropped during the studying period at both experimental areas in different period of time. Temperature inside the greenhouse at various places was recorded on hourly basis from 0700 hours to 1800 . The total area of greenhouse was divided into a number of grid points at $0 \mathrm{~m}$ (ground level), $1 \mathrm{~m}, 2 \mathrm{~m}, 3 \mathrm{~m}, 4 \mathrm{~m}, 5 \mathrm{~m}$ and $6 \mathrm{~m}$ (cover) height. The study revealed that there was temperature gradient existed in air temperature at different grid points inside the naturally ventilated greenhouse. In morning hour east side of the greenhouse exhibited more temperature as compared with west side greenhouse. Similarly, during evening time the temperature of the east side of the greenhouse was lower than the west side. At $5 \mathrm{~m}$ and $6 \mathrm{~m}$ height, from where hot air mass leaving the greenhouse temperature were recorded more as compared with other part of the greenhouse. The present study is helpful for deciding management procedure for crop production inside the greenhouse.

\section{Introduction}

Vegetable production in greenhouse is known as protected cultivation which not only produces more yield but off-season production of vegetable is also possible with it. Inside the greenhouse crop is grown under almost controlled environment due to envelope effect. In naturally ventilated greenhouse, air circulation is mainly responsible for cooling of greenhouse. The ideal range of temperature for crop production inside the greenhouse is about $16^{\circ} \mathrm{C}$ to $36^{\circ} \mathrm{C}$. During the hot summer month inside 
temperature of greenhouse increases drastically and it is more than the outside temperature. Foggers are helpful to control the temperature and to bring the high temperature to desired range. But in winter season when greenhouse has to kept warm to support the plant's vital activities, curtains are down from all sides to insure that cool air mass from outside should not affect the inside environment. The temperature inside the greenhouse varies with height of greenhouse and its orientation i.e. north, south, east and west direction. Orientation of greenhouse and position of sun during daytime plays an important role for maintaining temperature inside the greenhouse. During early morning eastside of the greenhouse warms up early as compared with west side of the greenhouse, whereas during evening hours eastside has relatively less temperature as compared with west side.

During noon time soil surface temperature is lower than that of temperature at $6 \mathrm{~m}$ high greenhouse cover. The environmental condition inside the greenhouse is different than the outside environment. The constituents of the greenhouse make it possible to have different microclimate as compared with outside. Kasza (1993) conducted a study on microclimate and discussed that greenhouse microclimate is influenced by heat flow and conduction, vapour diffusion, external temperature, solar radiation and air vapour content. The most important characteristics of greenhouse microclimate are temperature and vapour content. Any change in them can be described by differential equations that can be solved by the finite element method or the boundary element method.

The performance of a natural ventilated large scale greenhouse and microclimatic condition were demonstrated by Demrati et al., (2001) and they reported the daily evolution of outside global radiation, air temperature and humidity and even wind speed and direction varied in a very similar way, from one day to another (except for nighttime temperature). The periodic regime of the wind was evidenced by the high correlation (coefficient of determination $\mathrm{R}^{2}$ of 0.74 for 960 points of measurements) existing between wind speed and global radiation and between wind direction and time of the day.

Inside microclimatic conditions were characterized by a high solar transmission (around 60 percent) and a moderate diurnal elevation of temperature $\left(3-5^{\circ} \mathrm{C}\right.$ with reference to the outside). However, inside temperature at nighttime was similar to the temperature outside the greenhouse. Inside air humidity increased with respect to outside was rather weak but when combined with the moderate diurnal temperature elevation indicated that the greenhouse ventilation rate was high. Study shows evidence of a strong vertical gradient of leaves temperature, reaching $7^{\circ} \mathrm{C}$, between the young leaves at the top of the canopy ( $3-5 \mathrm{~m}$ high), and the old leaves (less than $3 \mathrm{~m}$ high).

Sharan and Madhvan (2010) conducted research to develop greenhouse technologies which economically control water and energy in order to improve farming in water-scarce, hot, semi-arid regions of north-west India, Ahmedabad, Gujarat. Tomatoes were grown in the greenhouse. They concluded that in the cooler months, a regime of natural ventilation and top shading kept the greenhouse temperature close to ambient temperature. Cropping could be done through the spring and early summer. Heating was affectively achieved with ETHE in cold nights of December and January keeping the inside temperatures well above $12^{\circ} \mathrm{C}$. Yields were $68 \mathrm{t} / \mathrm{ha}$ - nearly twice the open field production, while the water used $(266 \mathrm{~mm})$ was nearly half of the open-fields usage. 
Crop cultivation under protected structure is beneficial venture (Biwalkar et al., 2015; Biwalkar and Jain, 2014). It is important to know the behavior of structure for taking management steps.

Keeping in view the importance of thermal regime inside the naturally ventilated greenhouse, the present study was carried out to characterize various points inside the greenhouse on the basis of temperature.

\section{Materials and Methods}

A $560 \mathrm{~m}^{2}$ naturally ventilated greenhouse (Fig. 1) was constructed at the research farm of Department of Soil and Water Engineering, Punjab Agricultural University, Ludhiana. A similar greenhouse was also constructed at Krishi Vigyan Kendra, Faridkot. Capsicum was cropped during the studying period at both experimental areas in different period of time. Temperature inside the greenhouse at various places was recorded on hourly basis from 0700 hours to 1800 .

Thermo-hygrometer was used to record the temperatures. The total area of greenhouse was divided into a number of grid points at 0 $\mathrm{m}$ (ground level), $1 \mathrm{~m}, 2 \mathrm{~m}, 3 \mathrm{~m}, 4 \mathrm{~m}, 5 \mathrm{~m}$ and $6 \mathrm{~m}$ (cover) height. There were 15 points for recording air temperature from $0 \mathrm{~m}$ to $4 \mathrm{~m}$ height (Fig. 2), whereas there were only 10 points of observation at $5 \mathrm{~m}$ and $6 \mathrm{~m}$ height (Fig. 3).

At every grid point from $0 \mathrm{~m}$ (ground surface) to $6 \mathrm{~m}$ (greenhouse cover) temperature was recorded on hourly basis. In the crop was transplanted in the month of September. Inside the naturally ventilated greenhouse, gutter was installed at $4 \mathrm{~m}$ height and air vent (top arc) was provided at $6 \mathrm{~m}$ height. Bottom arc and top arc were started from $4 \mathrm{~m}$ height and ended at $6 \mathrm{~m}$ height.

\section{Results and Discussion}

The present study on temperature regime clearly showed that there is temperature variation inside the greenhouse horizontally and vertically. The data recorded for air temperature was started from 0700 hours to 1800 hours. The pattern of temperature inside the greenhouse showed that there were temperature gradient existed between these points. The study conducted at Ludhiana reveals that the northern side of the greenhouse, temperature was recorded slightly lower than the southern side temperature. This was due to the fact that southern side of the structure continuously received the solar radiation during the day time as sun facing side but the northern side acted as leeward side of the structure.

Temperature under different layers of the greenhouse at various time segments from morning hours to evening hours revealed that there were temperature difference occurred between different layers of the air i.e $0 \mathrm{~m}, 1$ m, $2 \mathrm{~m}, 3 \mathrm{~m}, 4 \mathrm{~m}, 5 \mathrm{~m}$ and $6 \mathrm{~m}$ height (Fig. 4 to 9). In these figures, $x$-axis has been presented as the length of the greenhouse $(0$ to $16 \mathrm{~m}$ ) and on y-axis has been presented by width of the greenhouse ( 0 to $24 \mathrm{~m}$ ). In $\mathrm{x}$-axis $8 \mathrm{~m}$ distance shows the center of the greenhouse lengthwise and in $y$-axis $12 \mathrm{~m}$ distance shows the center point of the greenhouse widthwise.

Figure 4 to 9 presents the temperature regime on $10^{\text {th }}$ January 2017 at 11 AM. 11 AM gives a relatively average temperature (neither minimum nor maximum) that is why it was represented graphically. From Figure 4, it is clear that at the center point, the temperature was recorded as maximum $\left(13.9^{\circ} \mathrm{C}\right)$; that shows that the moment of air mass at the center of the greenhouse was minimal as compared to the other parts of the greenhouse. Inside the greenhouse there was a belt from 5 
$\mathrm{m}$ to $15 \mathrm{~m}$ which was having relatively high temperature followed by the maximum temperature at the center. Ground surface temperature increases from morning to evening. The minimum temperature $\left(12.5^{\circ} \mathrm{C}\right)$ was recorded at the north-western part of the greenhouse started from $16 \mathrm{~m}$ to $24 \mathrm{~m}$ of its width; the patch is having a $6 \mathrm{~m}$ width.

Figure 5 shows the temperature distribution near the crop canopy. At $1 \mathrm{~m}$ height the temperature distribution is different than that of ground level at $0 \mathrm{~m}$. The center point is hotter $\left(14.0^{\circ} \mathrm{C}\right)$ than all other area inside the greenhouse, but the next hotter area has a belt of distances from $4 \mathrm{~m}$ to $12 \mathrm{~m}$. The colder area started from the $12 \mathrm{~m}$ widthwise and goes up to $24 \mathrm{~m}$, whereas lengthwise it has the maximum width of $6 \mathrm{~m}$. This region is related with evapotranspiration and hence the cooler area has more extent than the hotter area. The coolest area has temperature as $\left(13.0^{\circ} \mathrm{C}\right)$. At this height perforation is provided from all sideswhich allowed the air mass circulation along with evapotranspiration consequently there was more area under the low temperature at $1 \mathrm{~m}$ height.

Figure 6 to 8 shows the air temperature at $2 \mathrm{~m}$, $3 \mathrm{~m}$ and $4 \mathrm{~m}$ height. Heating pattern inside the greenhouse at these heights were almost same but as the elevation increased temperature also increased from $14.4^{\circ} \mathrm{C}$ to $14.90^{\circ} \mathrm{C}$ (maximum temperature) and $13.0^{\circ} \mathrm{C}$ to $13.7^{\circ} \mathrm{C}$ (minimum temperature) respectively. Center part of the greenhouse was the hottest part and at sides it was relatively cooler. In this area air circulation was more as compared with $1 \mathrm{~m}$ height but due to some more elevation this area experienced more temperature as compared with ground surface and canopy surface. Air mass at low temperature and moist air (due to evapotranspiration) was heavier and as and when air mass got heated up it started moving upward toward air vent at $6 \mathrm{~m}$ height.
Therefore, when moving from ground surface to $6 \mathrm{~m}$ height, at every segment vertically, there was temperature variation from cool air mass to hot air mass.

Figure 9 shows the area from where hot air mass leaving the structure as natural ventilation. In naturally ventilated greenhouse generally 20 percent of the total area is provided as perforation in lower portion (apron) and 10 per cent perforation at top arc as air vent. The southern side of the structure exhibited as hotter area than the northern side as cooler area. Again at the center portion it was hottest $\left(15.45^{\circ} \mathrm{C}\right)$ as compared with all other areas at different elevation.

Thermal behavior of a naturally ventilated greenhouse at Krishi Vigyan Kendra, Faridkot on $10^{\text {th }}$ January, 2017 is presented in Figure 10 to 13 . Inside temperature of the greenhouse gradually increased with increase in time for all cases. At ground level the movement of air was restrict due to plant population. For different grid points at each layer ( $0 \mathrm{~m}$ to $6 \mathrm{~m}$ height) there were 15 stations and are presented by different lines for different heights. Figure 10 represents the temperature regime of greenhouse in morning hours i.e. 0700, 0800 and 0900 hours respectively. Station number 1 to 5 presents the recording stations located in southern side of the greenhouse, station number 6 to 10 presents the central portion of the greenhouse and station number 11 to 15 presented by the northern side of the greenhouse. At the height of $5 \mathrm{~m}$ and $6 \mathrm{~m}$ there were only 10 recording points and central grid was absent at $5 \mathrm{~m}$ and $6 \mathrm{~m}$ height.

Figure 10 shows that the central part of the greenhouse recorded more temperature as compared with the sides of the greenhouse. At any layer of observation grids, stations at southern side recorded more temperature that the northern side, but the temperature at the 
center was recorded maximum for all cases. At 0700 hours the temperature was recorded minimum. Same station for different time segment i.e. 0700, 0800 and 0900 hours recorded high temperature each time as day time increases from 0700 to 1300 and after that there was decrease in temperature. Trend for morning hour's temperature regime was almost similar at all the stations. Some deviation in trend is mainly due to the cold breeze at $4 \mathrm{~m}$ height (near gutter) where cladding material has affected the temperature of air mass directly.

During noon time i.e. 1000, 1100 and 1200 hours (Fig. 11), temperature of air inside the greenhouse increased at fast rate due to the position of the sun as it reaches toward the solar noon. For all three time segment trend of the temperature regime recorded were similar. But at this period of time, circulation of air mass within the greenhouse due to heating of air mass was increased. Moist and colder air mass due to heating effect started moving towards the air vent at $6 \mathrm{~m}$ height. Consequently, there was a gap created between $4 \mathrm{~m}, 5 \mathrm{~m}$ and $6 \mathrm{~m}$ height lines. During afternoon period of time i.e. 1300, 1400 and 1500 hours (Fig. 12) the air temperature inside the greenhouse reached at maximum.
The lines representing different time segment shows that there was a significant temperature difference between ground surface and at $6 \mathrm{~m}$ height. At $5 \mathrm{~m}$ and $6 \mathrm{~m}$ height there was a difference of $2^{\circ} \mathrm{C}$ which was highest among all points of observation.

Figure 13 shows the temperature gradient at different stations during evening hours. The trend of the temperature regime for all stations was similar. The deviation of trend line between $5 \mathrm{~m}$ and $6 \mathrm{~m}$ height at 1600 hour is due to the continuous heating of greenhouse from inside but at 1700 hours due to cool breeze with drizzling for very short time drastically changes the temperature of the cladding material at $6 \mathrm{~m}$ height. For all the stations trend of temperature decreasing were recorded almost in same manner.

Table 1 presents the average air temperature inside the greenhouse on 11 April, 2017 at Krishi Vigyan Kendra, Faridkot. From table it is evident that air temperature of inside air increases as day time increases and at $6 \mathrm{~m}$ height the air temperature was recoded maximum as the hot air mass lifted up and starts moving out of the greenhouse through air vent.

Table.1 Average air temperature inside the green house on 11 April 2017 at Faridkot

\begin{tabular}{|c|c|c|c|c|c|c|c|c|}
\hline \multirow{2}{*}{$\begin{array}{c}\text { Time } \\
\text { (hours) }\end{array}$} & \multicolumn{7}{|c|}{ Vertical temperature regime inside greenhouse at different heights $\left({ }^{\circ} \mathbf{C}\right)$} \\
\hline $\mathbf{0 7 0 0}$ & $0 \mathrm{~m}$ & $1 \mathrm{~m}$ & $2 \mathrm{~m}$ & $3 \mathrm{~m}$ & $4 \mathrm{~m}$ & $5 \mathrm{~m}$ & $6 \mathrm{~m}$ \\
\hline $\mathbf{0 8 0 0}$ & 24.8 & 25.3 & 25.8 & 26.6 & 27.8 & 29.7 & 30.8 \\
\hline $\mathbf{0 9 0 0}$ & 25.4 & 26.0 & 26.6 & 28.2 & 29.5 & 30.9 & 31.3 \\
\hline $\mathbf{1 0 0 0}$ & 26.3 & 26.5 & 27.1 & 28.9 & 30.5 & 32.9 & 33.3 \\
\hline $\mathbf{1 1 0 0}$ & 27.2 & 27.5 & 28.2 & 29.7 & 31.6 & 33.0 & 34.5 \\
\hline $\mathbf{1 2 0 0}$ & 28.4 & 28.8 & 29.4 & 30.5 & 32.3 & 34.4 & 35.9 \\
\hline $\mathbf{1 3 0 0}$ & 29.5 & 30.1 & 30.7 & 31.8 & 33.5 & 35.6 & 36.4 \\
\hline $\mathbf{1 4 0 0}$ & 31.7 & 31.5 & 32.1 & 33.7 & 34.8 & 36.8 & 37.5 \\
\hline $\mathbf{1 5 0 0}$ & 31.9 & 32.7 & 33.8 & 34.9 & 36.2 & 38.4 & 39.5 \\
\hline $\mathbf{1 6 0 0}$ & 29.2 & 31.9 & 32.4 & 34.2 & 35.8 & 37.2 & 38.7 \\
\hline $\mathbf{1 7 0 0}$ & 28.5 & 29.1 & 28.6 & 29.8 & 31.4 & 35.3 & 36.5 \\
\hline $\mathbf{1 8 0 0}$ & 26.9 & 27.8 & 28.1 & 29.6 & 30.2 & 34.0 & 35.3 \\
\hline
\end{tabular}




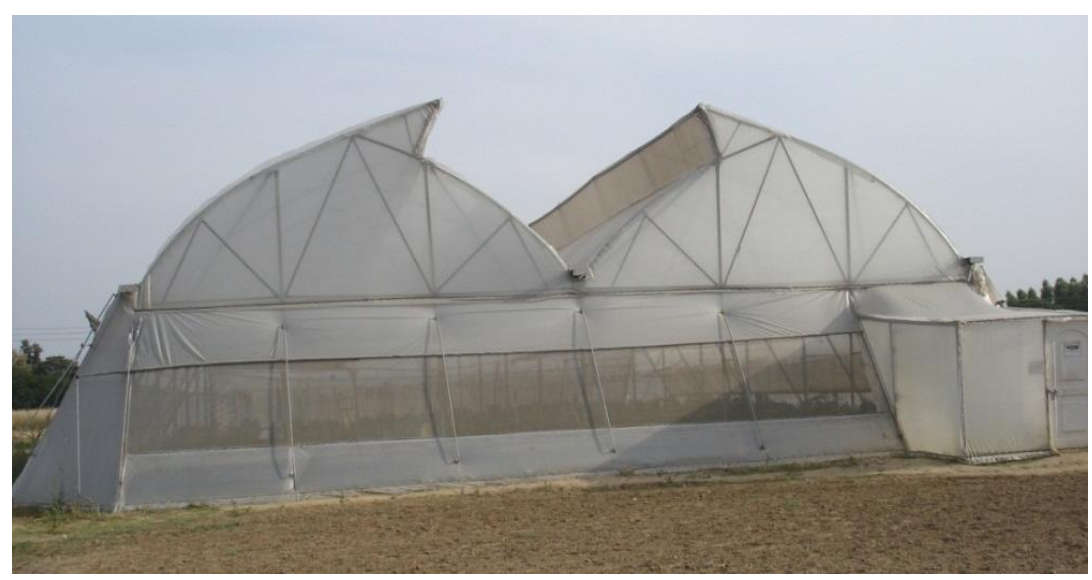

Fig.1 Greenhouse structure having floor area of $560 \mathrm{~m}^{2}$

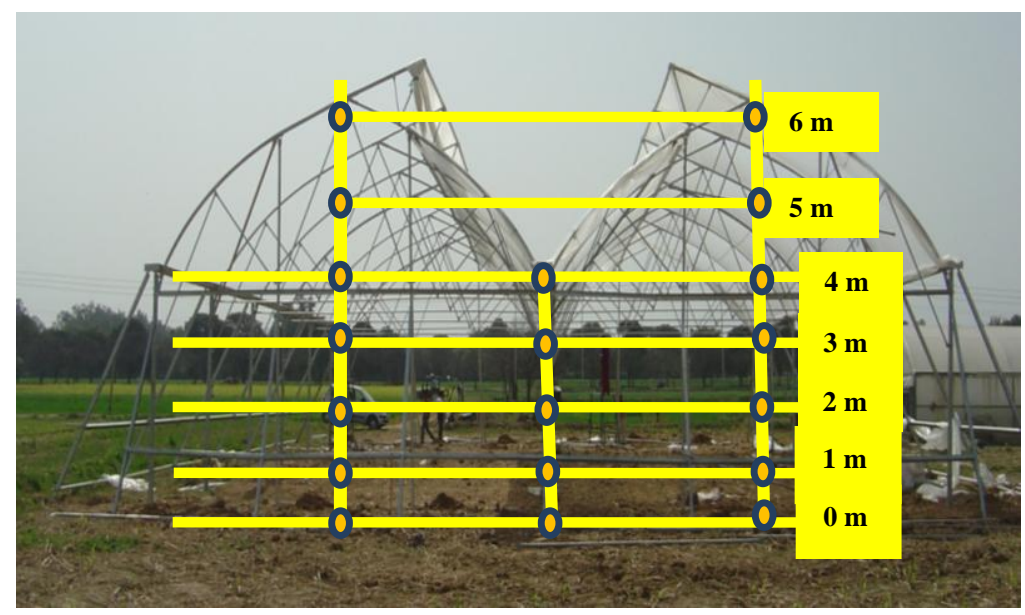

Fig.2 Temperature measuring grid points under greenhouse (lengthwise)

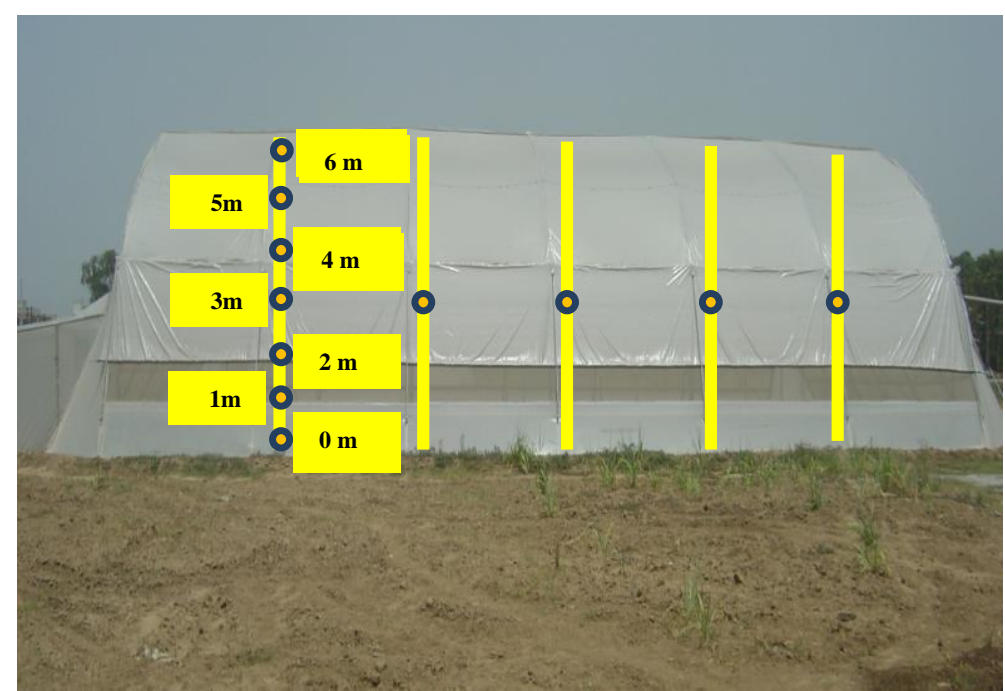

Fig.3 Temperature measuring points under greenhouse (widthwise) 


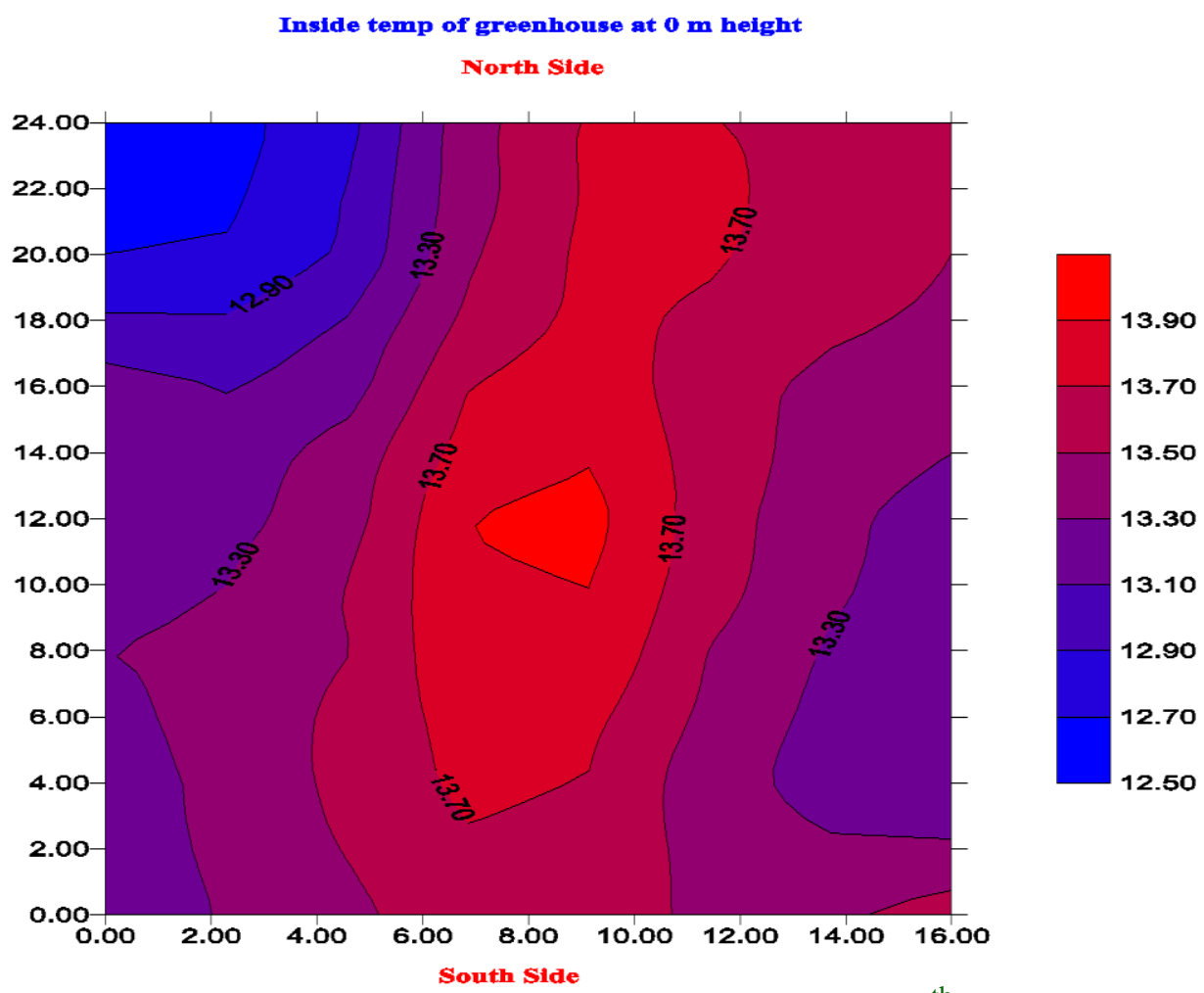

Fig.4 Temperature regime of air at ground level $(0 \mathrm{~m})$ on $10^{\text {th }}$ January at 11 am

Inside temp of greenhouse at $1 \mathrm{~m}$ height

North Side

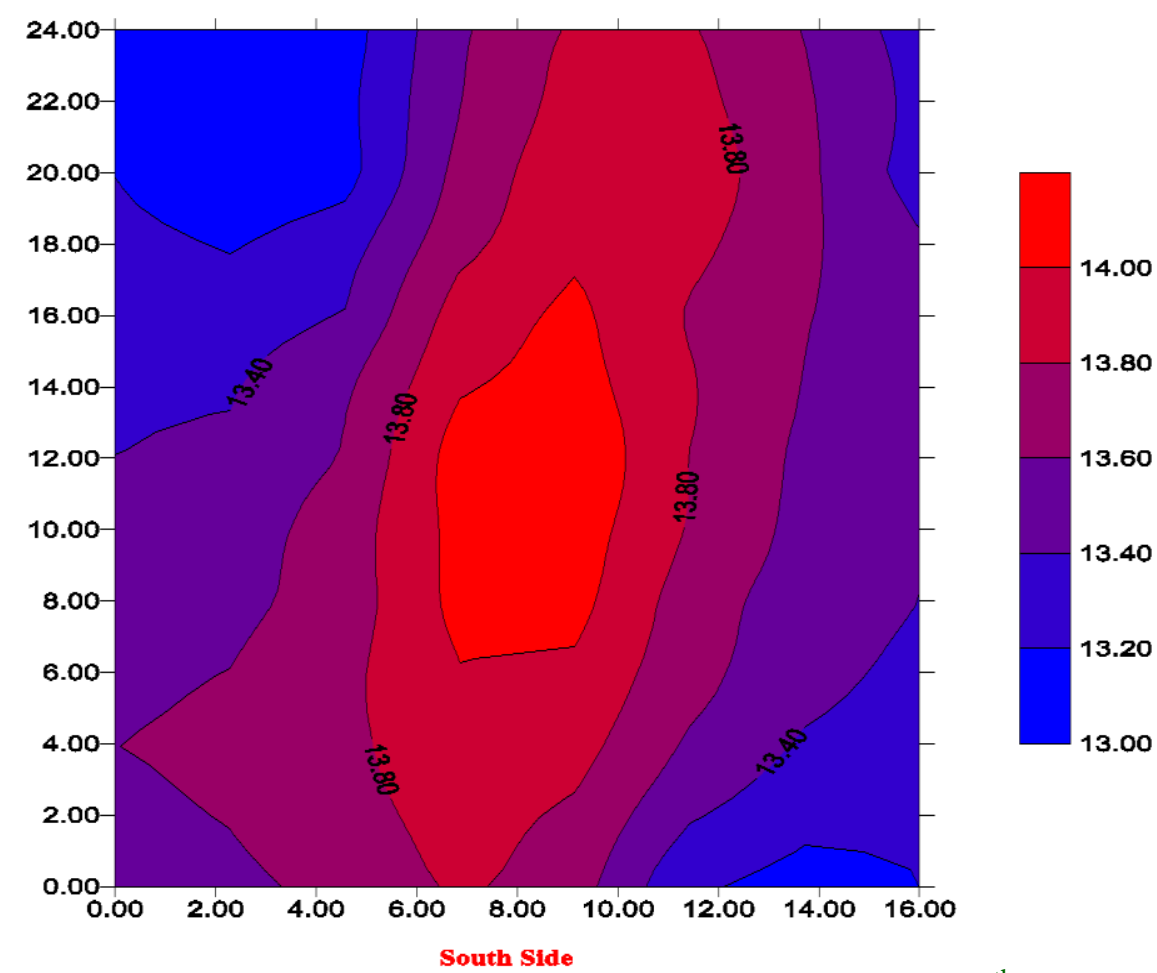

Fig.5 Temperature regime of air at $1 \mathrm{~m}$ height (Crop canopy) on $10^{\text {th }}$ Januaryat $11 \mathrm{am}$ 
Inside temp of greenhouse at $2 \mathrm{~m}$ height

North Side

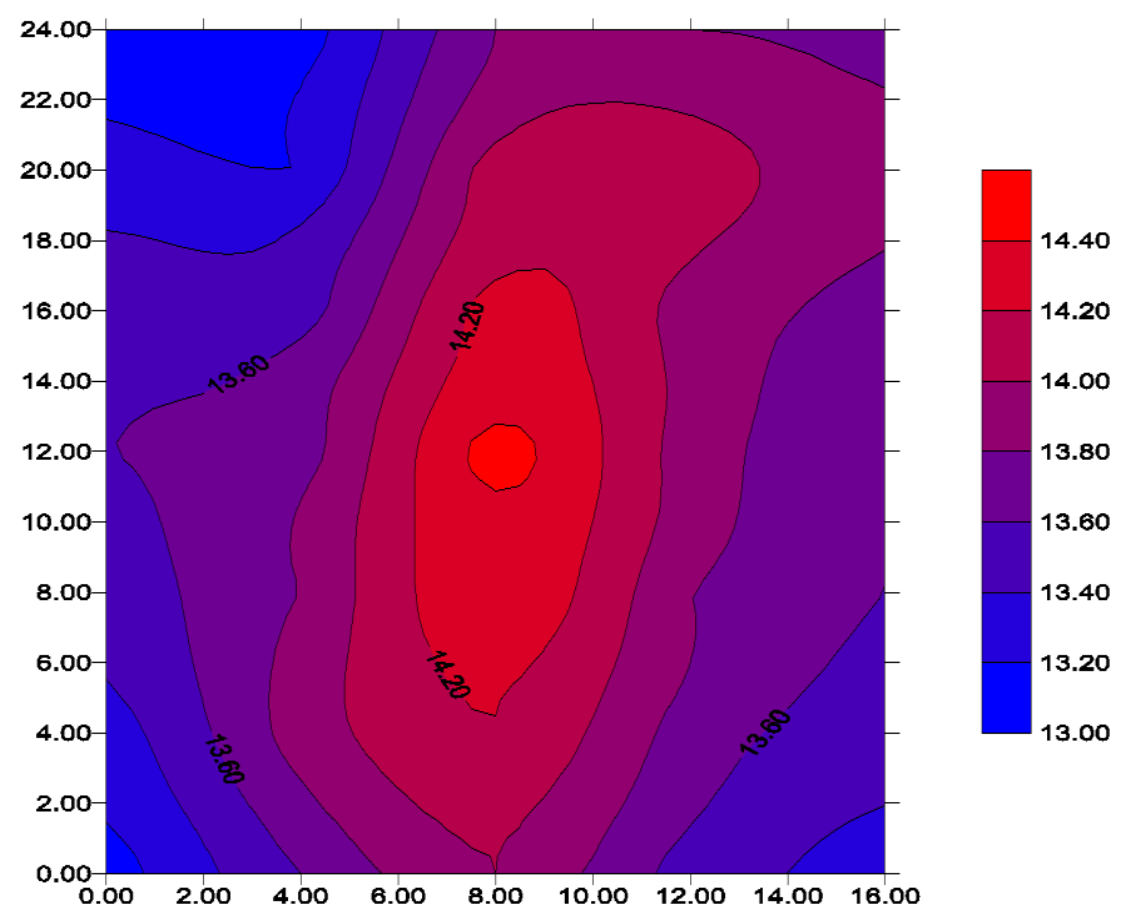

South Side

Fig.6 Temperature regime of air at $2 \mathrm{~m}$ height (above crop canopy) on $10^{\text {th }}$ January at $11 \mathrm{am}$

Inside temp of greenhouse at $3 \mathrm{~m}$ height

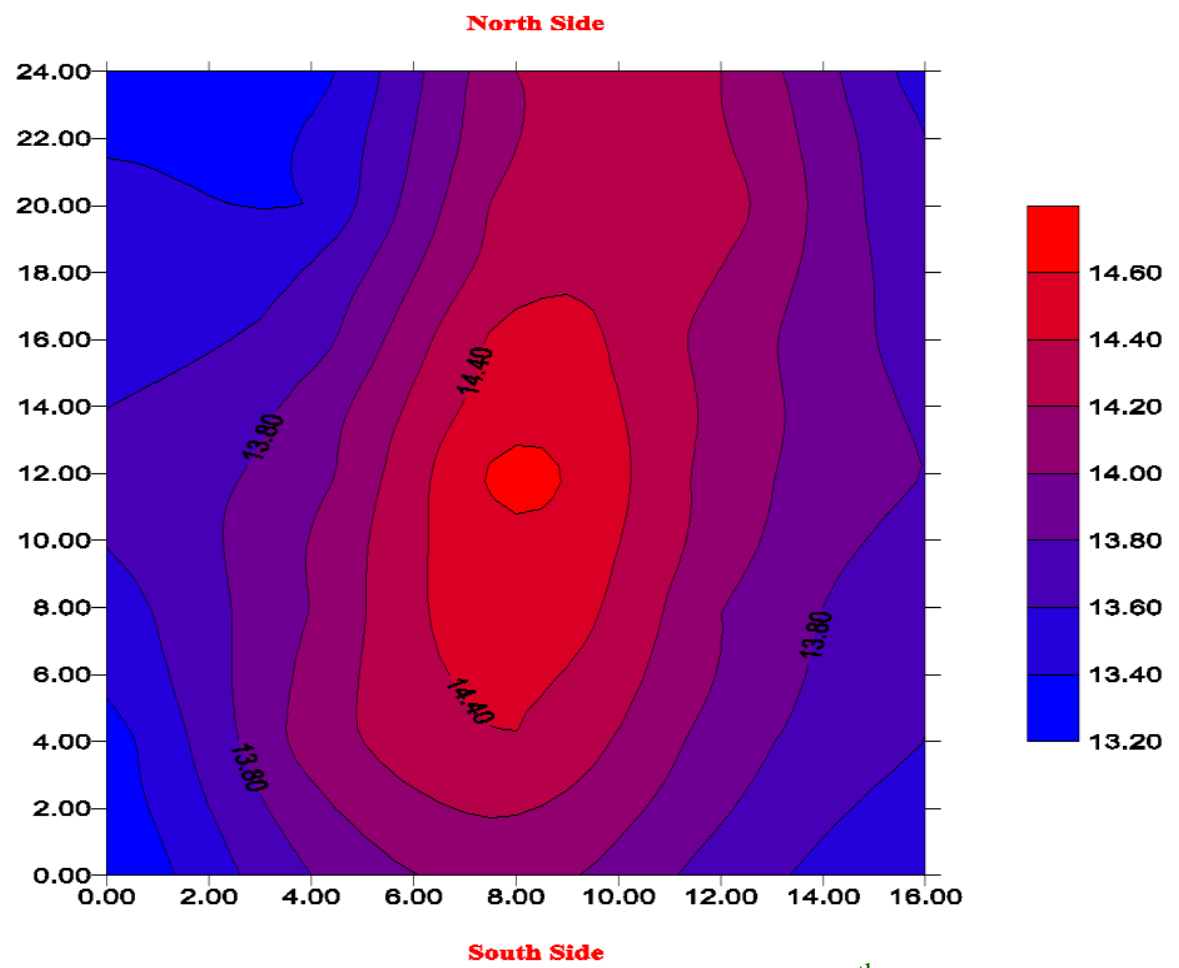

Fig.7 Temperature regime of air at $3 \mathrm{~m}$ height on $10^{\text {th }}$ January at $11 \mathrm{am}$ 
Inside temp of greenhouse at $4 \mathrm{~m}$ height

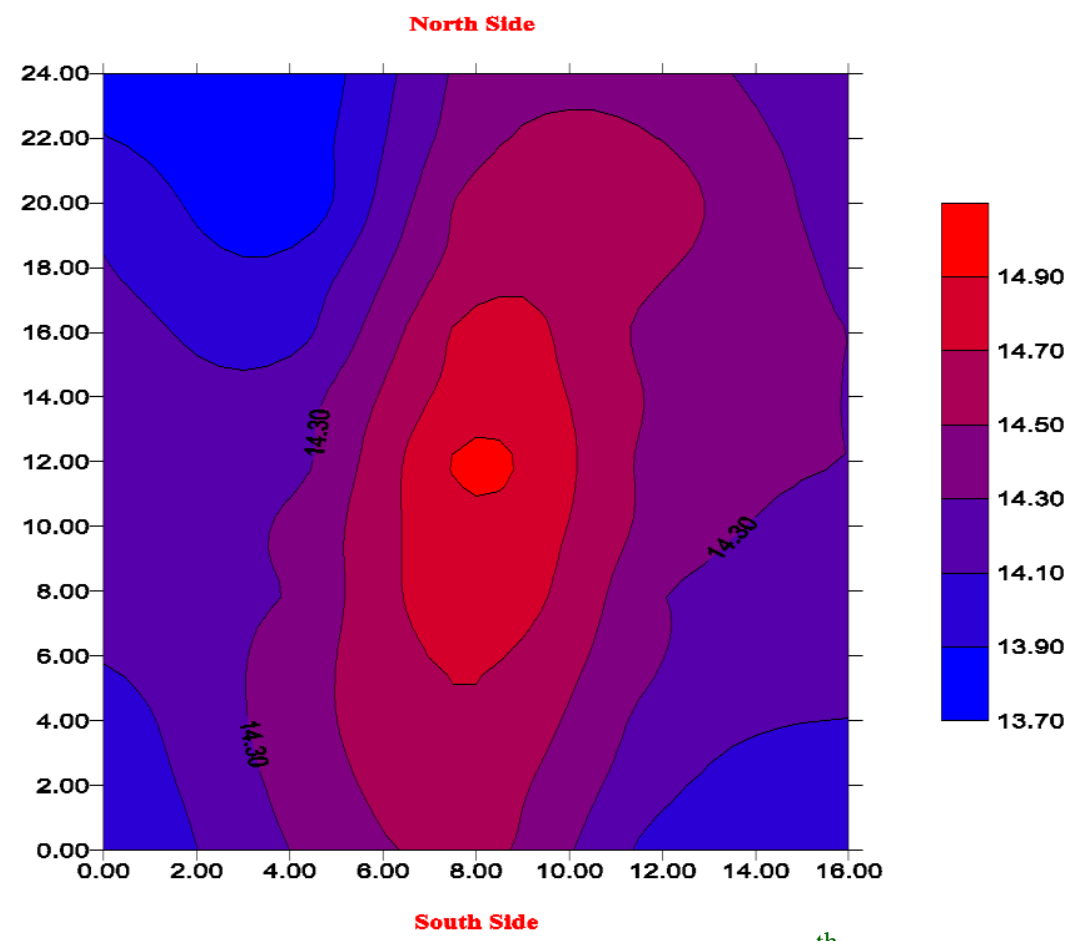

Fig.8 Temperature regime of air at $3 \mathrm{~m}$ height on $10^{\text {th }}$ Januaryat 11 am

Inside temp of greenhouse at $5 \mathrm{~m}$ height

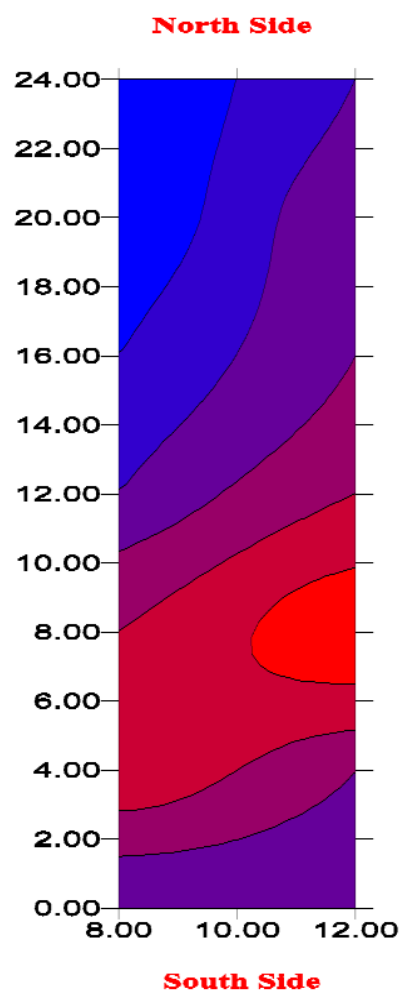

Inside temp of greenhouse at $6 \mathrm{~m}$ height

North Side

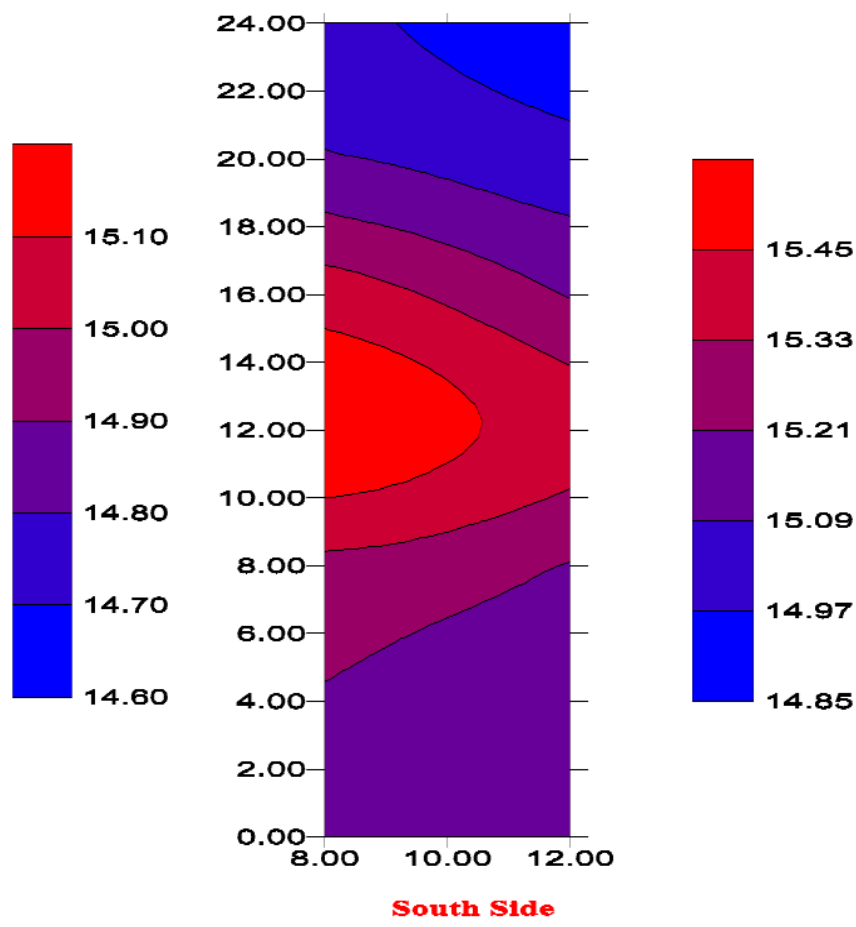

Fig.9 Temperature regime of air at 5 and $6 \mathrm{~m}$ height on $10^{\text {th }}$ Januaryat 11 am 


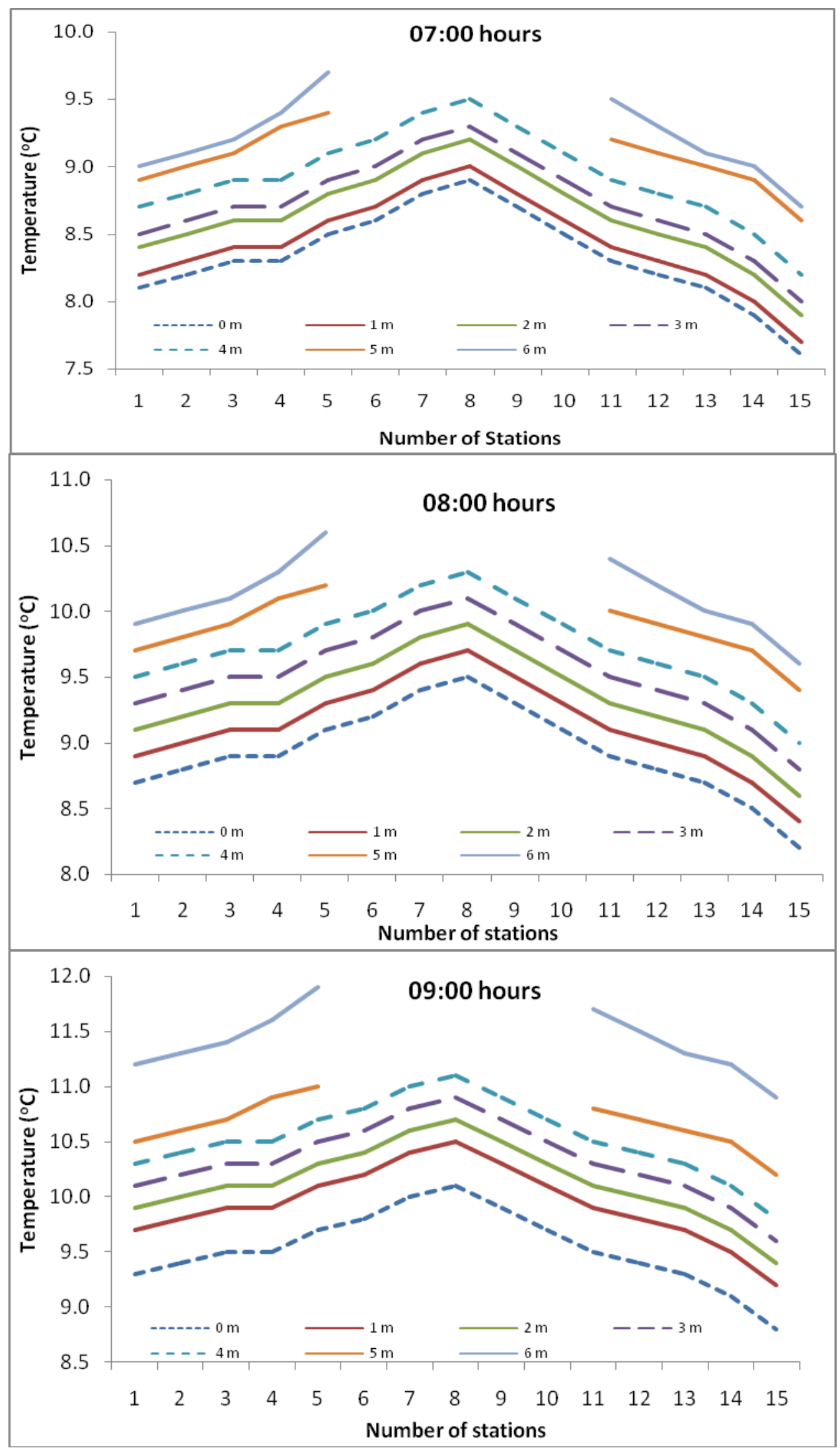

Fig.10 Recorded air temperature at various stations in morning time 


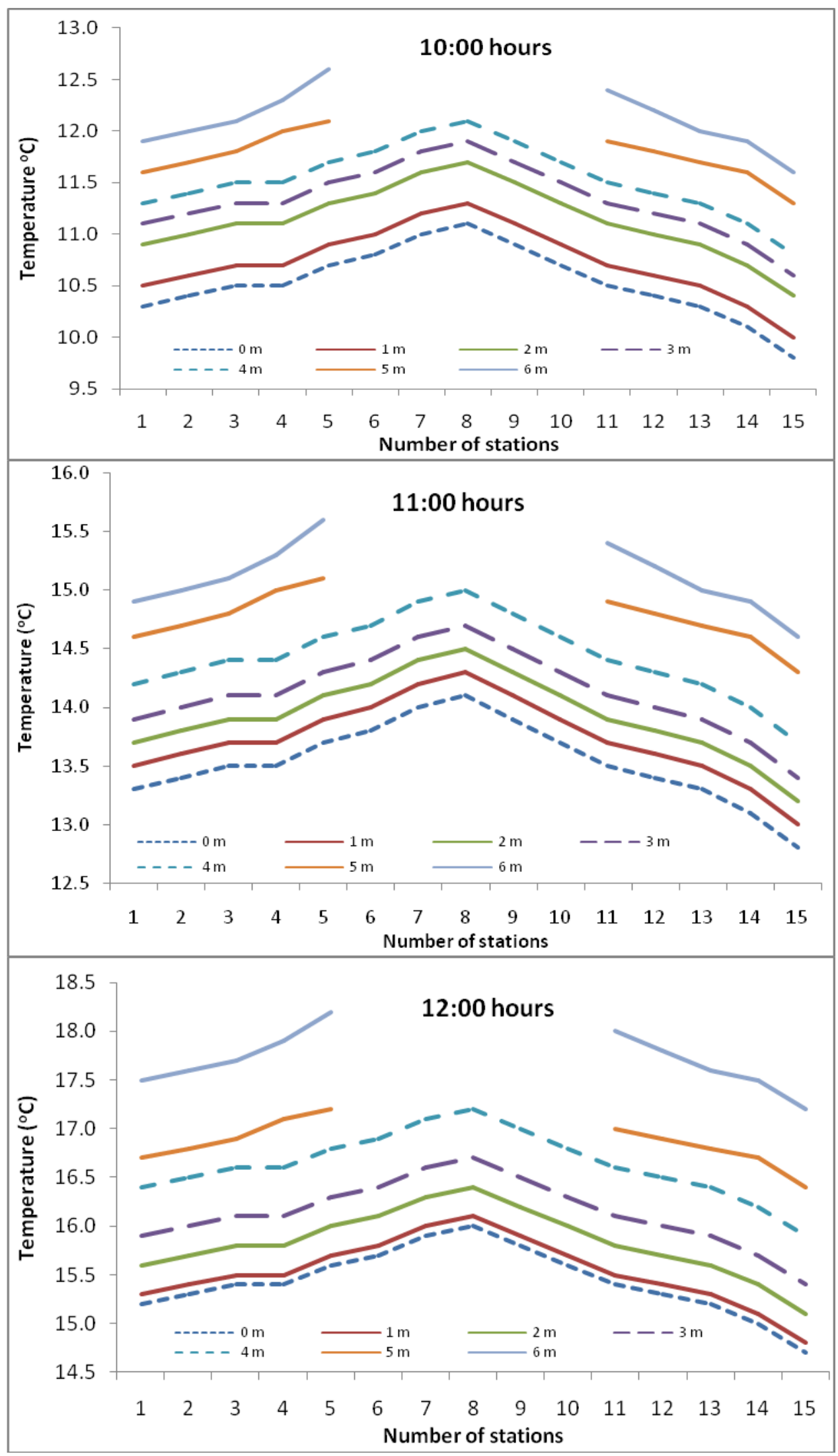

Fig.11 Recorded air temperature at various stations in noon time 
Int.J.Curr.Microbiol.App.Sci (2020) 9(4): 1140-1153

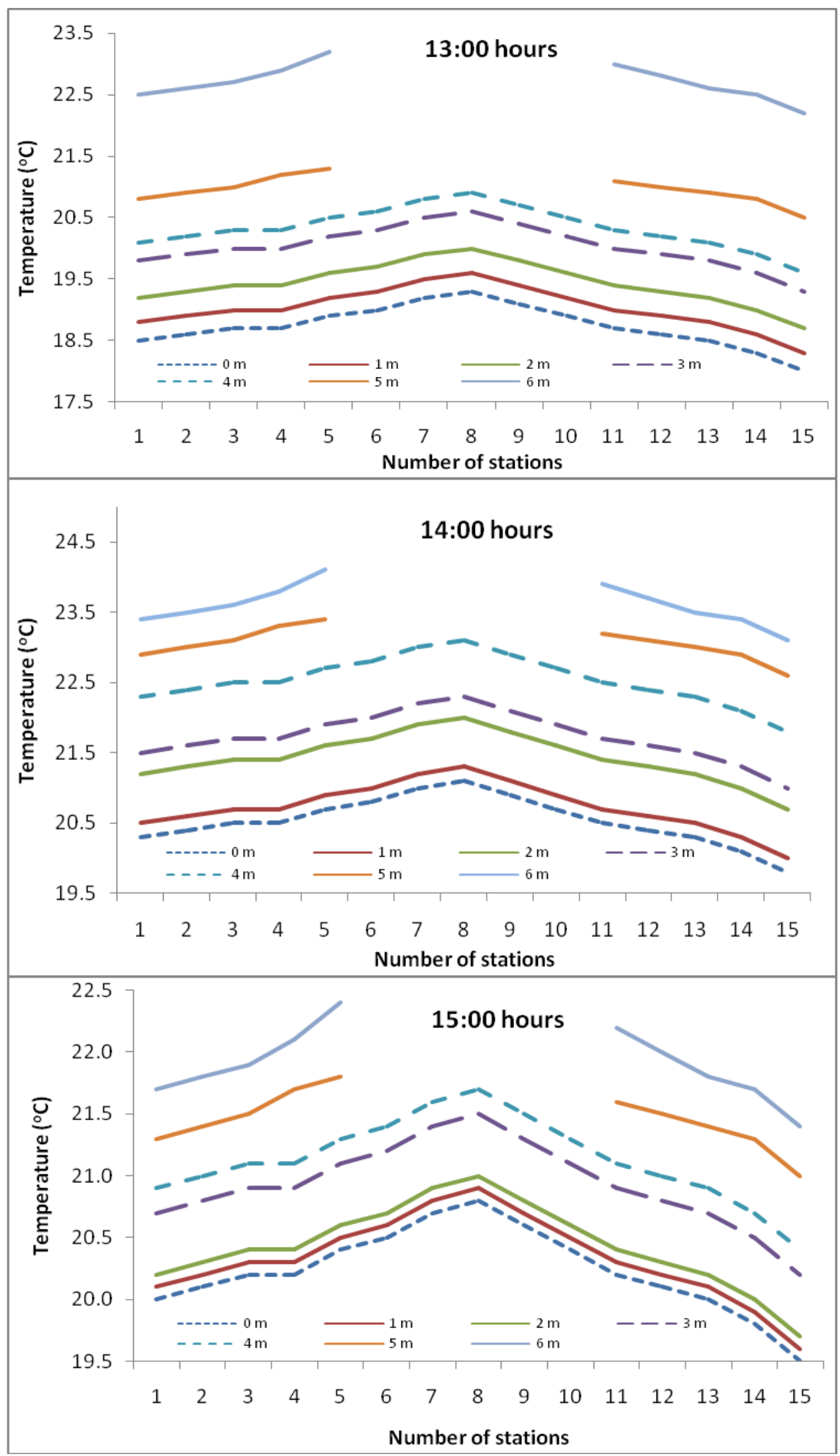

Fig.12 Recorded air temperature at various stations in afternoon time 


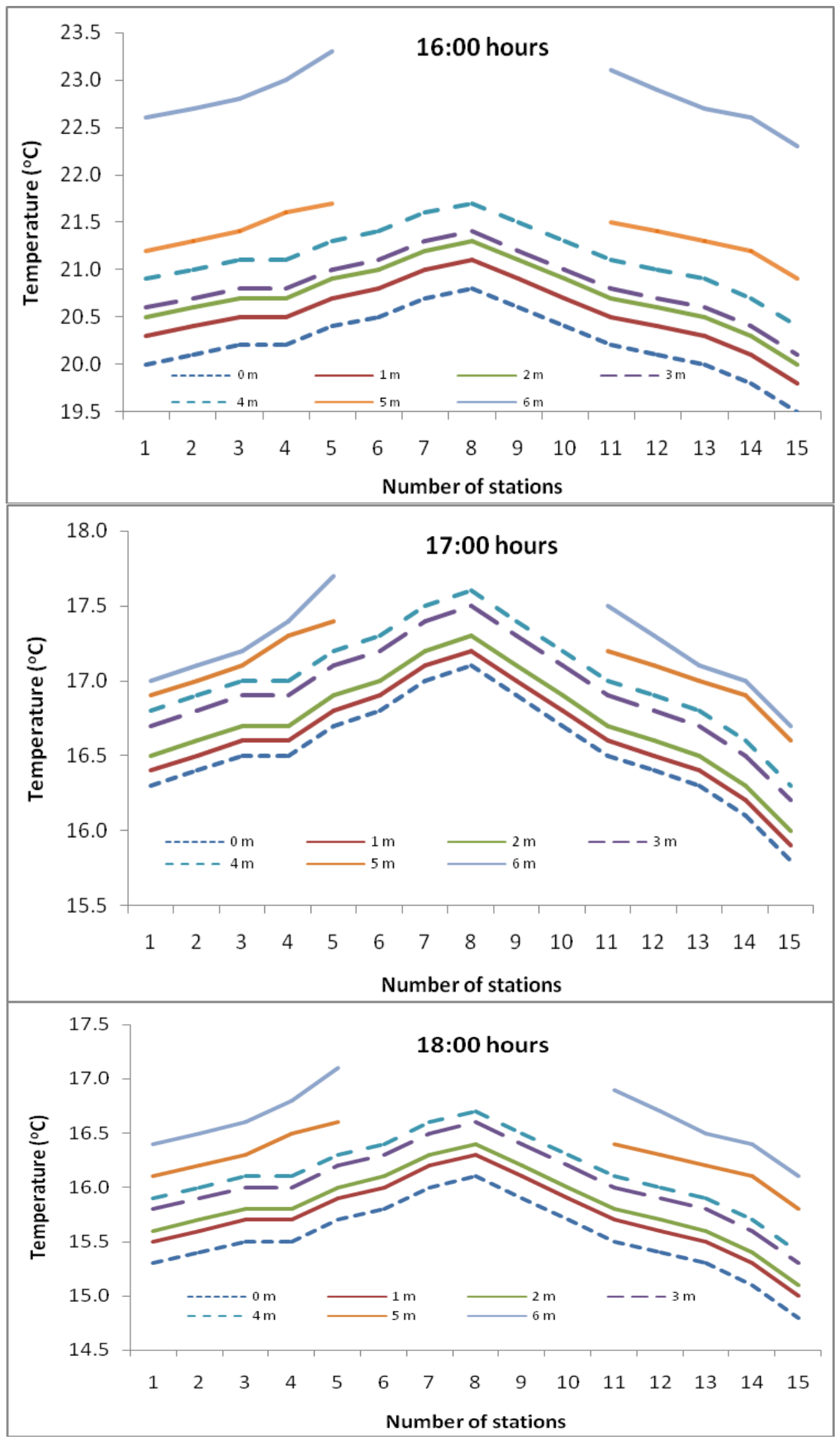

Fig.13 Recorded air temperature at various stations in evening time 
The present study revealed that there was temperature gradient existedin air temperature at different grid points inside the naturally ventilated greenhouse. In morning hour east side of the greenhouse exhibited more temperature as compared with west side greenhouse. Similarly, during evening time the temperature of the east side of the greenhouse was lower than the west side.

At ground level $(0 \mathrm{~m})$ and canopy surface (1m) the temperature regime was affected by presence of moist air and evapotranspiration. At $5 \mathrm{~m}$ and $6 \mathrm{~m}$ height, from where hot air mass leaving the greenhouse temperature were recorded more as compared with other part of the greenhouse. The air temperature inside the greenhouse increased as the day time increased. The present study is helpful for deciding management procedure for crop production inside the greenhouse.

\section{References}

Biwalkar Nilesh and Jain A K (2014) Economical evaluation of sweet pepper production under naturally ventilated greenhouse condition. Ann of Agri Bio Res 19(4): 669-72.

Biwalkar Nilesh, Singh K G, A K Jain, Rakesh Sharda, S K Jindal, Kulbir Singh and Neena Chawla 2015. Response of coloured sweet pepper (Capsicum annuum L. var. Grossum) to fertigation and irrigation levels under naturally greenhouse. Agriculture Research Journal (PAU)52 (1): 19-25.

Demrati H, T Boulard, A Bekkaoui and L Bouirden (2001) Natural ventilation and microclimatic Performance of a Large-scale Banana Greenhouse. J AgricEngg Res80 (3):261-271.

Kasza F (1993) Application possibilities of finite and boundary element methods in climate control design of greenhouse. Hungarian AgricEngg6:61-62.

Sharan Girja and T Madhavan (2010) Cropping in Semi-arid Northwest India in Greenhouse with Ground Coupling Shading and Natural Ventilation for Environmental Control. Inter J for Service Learning in Engg5 (1): 148-169.

\section{How to cite this article:}

Nilesh Biwalkar, Rakesh Kumar and Rakesh Sharda. 2020. Characterization of Temperature Regime under Capsicum Cropped Naturally Ventilated Greenhouse. Int.J.Curr.Microbiol.App.Sci. 9(04): 1140-1153. doi: https://doi.org/10.20546/ijcmas.2020.904.135 